\title{
LEMBAGA KEAGAMAAN, PANCASILA DAN STRATEGI PEMBERANTASAN KORUPSI
}

\author{
Ismail Marzuki \\ Universitas Nurul Jadid \\ Email: ismail.mz2805@gmail.com
}

\begin{abstract}
Abstrak
Penelitian ini membahas tentang sikap agama terhadap perilaku korup, tinjauan Filsafat Hukum Islam terhadap kejahatan korupsi dan peran yang dapat dilakukan oleh lembaga keagamaan dalam upaya memberantas korupsi. Mengingat lembaga keagamaan selama ini masih selalu fokus terhadap hal-hal yang berkaitan dengan ibadah mahdlah dan mengabaikan persoalan-persoalan konkret yang dihadapi bangsa, seperti korupsi. Di samping itu, dalam penelitian ini juga disinggung tentang konsep dan strategi pemberantasan korupsi dalam kacamata Pancasila karena Pancasila di samping sebagai budaya bangsa, di mana setiap tindak-tanduk masyarakat harus mencerminkan nilainilai Pancasila, juga sebagai falsafah bangsa yang menjadikan Pancasila sebagai sumber dari segala sumber hukum yang mestinya dapat dijadikan sebagai alat dalam memerangi masalah korupsi.
\end{abstract}

Kata kunci: Peran Lembaga Keagamaan, Pancasila, Strategi Pemberantasan Korupsi

\begin{abstract}
This study discusses religious attitudes toward corrupt behaviour, philosphy of Islamic law reviews about corruption and the role that can be done by religion institution for eradicating corruption. Religion institution in present time always focus about mahdlah matters and overlook the country vivid problems, like corruption. In the other hand, concepts and strategies to eradicate corruption from Pancasila point of view are mentioned because beside Pancasila as nation culture whereas source of public behaviour, also as nation's philosophy that makes Pancasila become a fundamental law, which should become tool for fighting corruption.
\end{abstract}

Keywords: The Role Of Religion Institution, Pancasila, Strategy for Eradicating Corruption.

\section{A. PENDAHULUAN}

\section{Latar Belakang}

Indonesia merupakan negara yang plural, kaya akan budaya, bahasa, suku dan sebagainya. Keanekaragaman tersebut tidak kemudian membuat bangsa Indonesia menjadi bangsa yang tercerai-berai, melainkan mampu hidup berdampingan secara harmonis. Keharmonisan ini dibuktikan dengan perilaku masyarakat yang santun, saling menghormati, dan tolong menolong terhadap kelompok masyarakat yang lain. 
Perilaku bangsa Indonesia yang demikian menggambarkan bahwa bangsa ini sangat menjunjung tinggi nilai-nilai moral-religius. Penghormatan terhadap nilai-nilai moral tersebut tercermin dalam ideologi bangsa Indonesia yaitu Pancasila. Nilai moralketuhanan yang tertuang dalam sila pertama mengamanatkan bahwa moral bangsa Indonesia merupakan manifestasi dari ajaran Tuhan. Sila kedua yang berisi tentang nilai moral-kemanusiaan membawa pesan bahwa moral bangsa Indonesia sangat menghargai dan menghormati hak asasi manusia. Begitu juga dengan nilai moral-persatuan dalam sila ketiga, yang sangat menjunjung tinggi persatuan bagi seluruh bangsa Indonesia. Selanjutnya, sila keempat merupakan pernyataan tentang nilai moral-permusyawaratan yang mengajarkan kepada bangsa Indonesia tentang pentingnya menghargai dan memperlakukan manusia/rakyat/warga negara sebagai pribadi yang juga memiliki derajat dan kedudukan yang sama. Diakhiri dengan moral-keadilan dalam sila kelima yang berisi tentang pentingnya mengatur hubungan antar warga negara dengan kekuasaan demi tercapainya keadilan bagi seluruh rakyat Indonesia.

Pancasila sebagai ideologi bangsa seyogyanya membumi dalam setiap perilaku masyarakat Indonesia. Tetapi realita di lapangan masih sangat jauh, ibarat api jauh dari panggang. Berbagai perilaku amoral seringkali tampil menghiasi berbagai media, baik media elektronik maupun media massa. Pemberitaan media yang selalu istiqomah tampil dan tak kunjung usai adalah masalah utama bangsa ini yaitu persoalan korupsi.

Korupsi merupakan masalah yang sangat serius, baik dengan frekuensinya yang kecil terlebih yang besar. Karena dampak atau akibat yang ditimbulkan sangat mengganggu tidak hanya terhadap perekonomian nasional, tetapi juga terhadap kehidupan berbangsa dan bernegara, misalnya tidak terealisasinya infrastruktur yang memadai, pembangunan sarana-prasarana menjadi terganggu, harga kebutuhan sandang, pangan dan papan tidak seimbang, dan sebagainya.

Secara yuridis-normatif, korupsi dikategorikan sebagai kejahatan luar biasa (extra-ordinary crime), ${ }^{1}$ sehingga pencegahan dan penyelesaiannya pun membutuhkan upaya-upaya dan langkah-langkah yang luar biasa pula. Berbagai upaya dan langkah melalui jalur litigasi sudah dilakukan, tetapi hasil yang dicapai masih belum optimal. Artinya, meskipun sudah banyak orang yang diputuskan bersalah karena korupsi oleh pengadilan dengan dikenakan sanksi pidana penjara dan denda, tetapi kehidupan

1 Penjelasan atas Undang-Undang Republik Indonesia Nomor 30 Tahun 2002 tentang Komisi Pemberantasan Tindak Pidana Korupsi. 
korupsi justru semakin tumbuh subur di masyarakat. Padahal esensi adanya penyelesaian korupsi melalui pidana adalah untuk menjerakan pelaku dan mencegah orang lain agar tidak melakukan tindak pidana korupsi. Meski demikian, upaya penyelesaian tindak pidana korupsi melalui jalur litigasi tidak boleh berhenti atau dihentikan, melainkan perlu terus ditingkatkan dan dikembangkan dengan berbagai jenis pidana yang dinilai dapat menjerakan pelaku korupsi. Karena tanpa adanya pertanggungjawaban pidana, maka bukan tidak mungkin perilaku koruptif akan semakin menjamur, disebabkan adanya pembiaran oleh negara terhadap pelaku korupsi.

Uraian di atas menunjukkan bahwa korupsi tidak akan selesai jika hanya mengandalkan jalur litigasi semata, melainkan perlu disandingkan dengan upaya-upaya non-litigasi. Tujuan utama dari penggunaan jalur non-litigasi dalam perkara korupsi yang dihadapi bangsa Indonesia adalah untuk memberikan kesadaran hukum akan bahaya korupsi bagi masa depan bangsa, dengan tidak hanya mengatakan "say no korupsi", tetapi dalam berperilaku juga tidak boleh koruptif. Dengan kata lain, jalur non-litigasi merupakan upaya pencegahan bagi masyarakat untuk tidak berperilaku koruptif.

Salah satu bentuk upaya non-litigasi dalam memberantas tindak pidana korupsi adalah melalui peran lembaga atau institusi keagamaan dan penghayatan serta pengamalan nilai-nilai Pancasila dalam membina dan membangun kehidupan berbangsa dan bernegara.

\section{Rumusan Masalah}

Berdasarkan uraian dalam latar belakang masalah di atas, maka rumusan masalah dalam penelitian ini adalah sebagai berikut:

1. Bagaimana peran institusi keagamaan dalam perang melawan tindak pidana korupsi ?

2. Bagaimana upaya memberantas perilaku koruptif perspektif Pancasila ?

\section{B. PEMBAHASAN}

\section{Peran Institusi Keagamaan Melawan Korupsi}

a. Sikap Agama Terhadap Korupsi 
Abdullah bin Umar pernah mengatakan bahwa Rasulullah SAW melaknat orang yang memberi suap dan orang yang menerima suap (la'ana Rasulullah SAW ar-rasyiya wa al-murtasyiya). ${ }^{2}$ Pemberi suap (ar-rasyi) biasanya adalah orang yang memiliki maksud untuk memuluskan suatu perkara yang salah menjadi tidak salah dan yang tidak berhak menjadi berhak. Sementara penerima suap (almurtasyi) umumnya merupakan pihak yang memiliki wewenang atau kekuasaan untuk merencanakan atau memeriksa atau menyelesaikan perkara yang menyangkut kepentingan ar-rasyi, akan tetapi ia menyalahgunakan wewenang tersebut. Pendek kata, risywah (suap-menyuap) adalah suatu pemberian jasa atau barang maupun sejenisnya kepada orang lain dengan maksud untuk mendapatkan sesuatu yang bukan haknya atau demi menghindarkan kewajiban yang semestinya ditunaikan atau ditanggungnya.

Lalu bagaimana dengan perantara suap antara ar-rasyi dan al-murtasyi, yang dikenal dengan sebutan ar-raisyi? Kendati mekanisme suap-menyuap bisa terjadi tanpa adanya pihak perantara, namun peranan pihak perantara tidak bisa diabaikan begitu saja, mengingat perantara biasanya adalah orang/pihak yang memiliki kedekatan khusus dengan pemilik wewenang atau kekuasaan. Dalam hadits yang lain Rasulullah SAW bersabda bahwa Allah melaknat pemberi suap, penerima suap dan perantara suap di antara keduanya dalam masalah hukum (la'anallahu ar-rasyiya wa al-murtasyiya wa ar-raisyi fi al-hukmi). ${ }^{3}$ Dalam hadist kedua ini terdapat tambahan diakhir yaitu fi al-hukmi, artinya laknat Allah dan Rasul-Nya hanya bagi mereka yang terlibat proses suap-menyuap dalam masalah hukum. Pembatasan risywah dalam bidang hukum bukan berarti menafikan risywah dalam aspek yang lainnya seperti politik, sosial dan sebagainya.

Sudah menjadi mafhum, bahwa setiap daging yang tumbuh dari harta hasil kejahatan (harta haram), maka api neraka lebih berhak atas daging tersebut. Hal ini menyiratkan bahwa segala upaya untuk menguasai atau memiliki harta orang lain melalui cara-cara jahat (antara lain; seperti penggelapan, pengkhianatan,

2 Abu 'Isa Muhammad ibn 'Isa ibn Tsaurat al-Turmuzi, Sunan al- Turmuzi (Jami' al-Shahih), Indonesia: Dahlan, t.t., kitab ahkam, no. 1257, juz 2, hal. 397. Abu Hasan mengatakan bahwa hadits ini shohih hasan.

3 HR. Ahmad, hadits ini dijadikan sebagai salah satu rujukan dalam Musyawarah Nasional VI Majelis Ulama Indonesia yang berlangsung pada tanggal 23-27 Rabi'ul Akhir/ 25-29 Juli 2000 M, yang membahas tentang Suap (Risywah), Korupsi (Ghulul) dan Hadiah kepada Pejabat, hadist ini kemudian terhimpun dalam Himpunan Fatwa Majelis Ulama Indonesia, hlm, 367. 
penipuan, dan pemerasan atas harta kekayaan negara yang merupakan salah satu unsur, sifat, atau karakter dari tindak pidana korupsi), tidak pernah dibenarkan dalam ajaran agama Islam dan kelak di akhirat neraka adalah tempat terbaiknya.

Selain itu, Rasulullah juga pernah memberikan deskripsi nyata mengenai seseorang yang memohon kepada Tuhan, tetapi ditolak. Deskripsi tersebut terpotret secara rinci sebagai berikut;

"Bahwa ada seorang laki-laki yang dalam sebuah perjalanan panjang, sehingga terlihat kusut dan kotor sekali rambutnya, tiba-tiba ia menengadahkan tangannya ke langit seraya berkata: “ya rabb.. ya rabb..”, padahal dibalik permohonannya itu, ia senang makan makanan haram, minum dengan minuman yang haram, pakaiannya diperoleh dari barang haram, dan perutnya pun kenyang dengan barang haram. Maka Nabi SAW menanggapi peristiwa tersebut dengan sabdanya; "bagaimana mungkin permohonannya dapat terkabul sementara ia senang akan hal-hal yang haram?"4

Sikap Rasulullah SAW yang demikian, karena secara dogmatis Allah SWT memiliki sifat yang Maha Baik dan senang terhadap hal-hal yang baik (innallaha ta'aala thoyyibun laa yaqbalu illa thoyyiban).$^{5}$

\section{b. Korupsi dalam Perspektif Filsafat Hukum Islam}

Ajaran Islam membawa misi yang orientasinya adalah membahagiakan semua makhluk, tidak hanya bagi penganutnya saja, tetapi juga bagi seluruh alam semesta. Orientasi ini tercermin dalam kalamullah QS; Al-Anbiya' ayat 107 (wa maa arsalnaaka illaa rahmatan lil-'aalamiin), bahwa Allah tidak mengutus Muhammad sebagai pembawa risalah Allah yakni Islam, melainkan untuk menjadi rahmat bagi semesta alam.

Rahmat bagi semesta alam dapat diartikan sebagai kemaslahatan bagi seluruh makhluk. Kemaslahatan secara filosofis merupakan sikap yang terusmenerus diupayakan untuk tidak melanggar lima (5) prinsip dalam hukum islam, yaitu menjaga agama (hifdz al-din), menjaga jiwa (hifdz al-nafs), menjaga

4 Ismail Marzuki, Melumpuhkan Tindak Pidana Pencucian Uang Dengan Hukum Pidana Islam, dipublikasikan di Jurnal Wajah Hukum, Vol. 1 No. 1, Oktober 2017, hlm. 5.

5 Imam Yahya bin Syarf ad-Din an-Nawawi, Matan Al-Arba'in An-Nawawiyah, Maktabah: Syaikh Salim ibn Sa'ad Nabhani, t.t, hlm. 17. 
keturunan (hifdzal-nasl), menjaga akal (hifdz al-aql), dan menjaga harta (hifdz almaal).

Kelima prinsip di atas populer di kalangan ahli hukum islam dengan sebutan al-maqashid asy-syari'ah. Abdul Wahab Khallaf mengatakan bahwa maksud umum disyariatkannya hukum islam (al-maqashid asy-syari'ah) adalah untuk merealisasikan kemaslahatan umat sebagaimana yang tertuang dalam lima (5) prinsip yang telah disebutkan di atas, baik yang bersifat primer (dharuriyyat), sekunder (hajiyyat), maupun tersier (tahsiniyyat) ${ }^{6}$

Sementara korupsi adalah bentuk penyimpangan terhadap kelima prinsip tersebut. Secara rinci bentuk-bentuk penyimpangannya ialah sebagai berikut:

1) Penyimpangan korupsi dalam hifdz al-din; Kendati korupsi tidak memiliki korelasi langsung dengan agama yang dianut seseorang, tetapi penggunaan sandi-sandi yang bernuansa religius dalam melakukan aksi tindak pidana korupsi sangat merusak reputasi agama itu sendiri, seperti istilah liqo' dan juz. Liqo’ dipahami sebagai bentuk persetujuan atau kesepakatan, sementara juz dipahami sebagai pengganti dari mata uang tertentu. Sejatinya, inilah yang dimaksud dengan penistaan terhadap agama, di mana seseorang melakukan kejahatan (terlebih kejahatan yang bersifat extra-ordinary crime), namun ia berlindung dibalik payung agama.

2) Penyimpangan korupsi dalam hifdz al-nafs; konsekuensi logis bagi pelaku korupsi adalah penderitaan atau nestapa baik secara fisik maupun sosial. Secara fisik, ia harus siap menempati dinginnya tempat dibalik jeruji besi. Selain itu, reputasi diri dan keluarganya di tengah-tengah masyarakat akan tercemar, sehingga kemungkinan masyarakat untuk memberikan posisi atau tempat-tempat penting di lingkungan masyarakat sulit untuk dicapai kembali.

3) Penyimpangan korupsi dalam hifdz al-nasl; dapat dikatakan bahwa semua orang tua menginginkan kehidupan keluarganya, terutama anak keturunannya layak dan tercukupi. Mencukupi kebutuhan keluarga, terutama anak dengan materi yang diperoleh dari hasil korupsi, sudah barang tentu sangat merugikan. Hal ini karena cepat ataupun lambat petaka

6 Abd Wahab Khallaf, Ilm Ushul al-Fiqh, Kairo: Dar al-Qalam, 1990, hlm. 198. 
buruk, adzab dan hinaan/celaan akan menimpanya. Sudah dijelaskan pada bagian sebelumnya bahwa setiap daging yang diberi asupan makanan haram, maka neraka adalah tempat terbaiknya. Oleh karena itu, setiap orang yang menyakini sabda Rasulullah tersebut tentu tidak akan berani membawa, memberi, dan menyuapkan nafkah haram kepada istri dan anakanaknya, karena hakikatnya ia sedang menyuapkan api neraka kepada keluarganya. $^{7}$

4) Penyimpangan korupsi dalam hifdz al-aql; di antara unsur yang melekat pada kejahatan korupsi adalah adanya penipuan, penggelapan, penyuapan, dan pengkhianatan di dalamnya. Akal yang terbiasa dihuni oleh unsur-unsur tersebut sangat berbahaya dan membahayakan orang lain. Dengan akal busuknya, ia dapat dengan mudah memperdaya rakyat dan tanpa disadarinya, ia sebenarnya juga telah mempersiapkan dirinya jatuh dalam kehinaan.

5) Penyimpangan korupsi dalam hifdz al-maal; agama secara eksplisit mengajarkan laa ta'kuluu amwaalakum bainakum bil bathil ${ }^{8}$ yang bermakna larangan untuk memakan harta dengan cara yang bathil. Kalimat laa ta'kuluu menurut pakar tafsir Indonesia Prof. Dr. Quraish Shihab tidak sekedar bermakna "memakan" dalam arti memasukkan sesuatu ke dalam mulut kemudian menelannya, tetapi juga bermakna "melakukan aktivitas atau cara memperoleh". ${ }^{9}$ Dengan demikian, dapat dipahami bahwa segala kegiatan yang dilakukan seseorang untuk memperoleh harta dengan cara yang batil, hukumnya haram, termasuk korupsi.

\section{c. Peran Institusi/Lembaga Keagamaan Dalam Memberantas Korupsi}

Keshalehan sebagai wujud perilaku orang beragama seyogyanya tidak hanya terpancar di masjid-masjid atau tempat-tempat ibadah lainnya, melainkan juga harus menjelma dalam kehidupan nyata sehari-hari. Ibadah bukan saja mencari jalan bagaimana cara mendekat pada Tuhan, tetapi juga tentang bagaimana

7 Muhammad Wildan Fawaid, Pengaruh Harta Halal dan Haram Pada Umat, dipublikasikan di Jurnal Masharif al-Syari'ah, Vol. 1 No. 2, November 2016, hlm. 69.

8 QS: An-Nisa' ayat 29.

9 Ismail Marzuki, Melumpuhkan.., hlm. 2. 
menerjemahkan pesan Tuhan agar membumi di tengah-tengah kehidupan masyarakat. Sehingga muncul istilah keshalehan individual dan keshalehan sosial yang merupakan manifestasi dari ibadah yang sesungguhnya.

Ibadah secara ta'rif adalah aktivitas yang dilakukan oleh seseorang untuk melawan hawa nafsu demi mengagungkan Tuhannya. ${ }^{10}$ Jika seorang muslim misalnya dalam shalat selalu mengucapkan kalimat takbir (Allahu Akbar), hal itu hakikatnya merupakan pesan agar dalam segala aspek kehidupannya ia selalu mengecilkan apapun selain Allah dan hanya mengagungkan Allah sebagai Dzat yang Maha Segalanya. Sebaliknya, bukan mengagungkan kekayaan, jabatan, pangkat dan kekuasaan yang sedang diamanahkan kepadanya.

Dilihat dari uraian di atas, maka dapat dipahami bahwa korupsi merupakan masalah moral. Sebagai masalah moral, maka agama tentu memiliki andil besar. Andil ataupun peran besar dari agama akan semakin kuat pengaruhnya terhadap masyarakat manakala dipelopori oleh institusi-institusi atau lembaga-lembaga keagamaan yang ada di masyarakat.

Selama ini, lembaga-lembaga keagamaan lebih banyak memainkan perannya dalam aspek ibadah mahdloh (mahdloh oriented), dari pada ibadah sosial (seperti persoalan-persoalan nyata yang dihadapi bangsa, yang meliputi; persoalan lingkungan, politik, ekonomi, termasuk masalah korupsi). Padahal esensi adanya lembaga keagamaan tidak hanya menjadi pusat penyelesaian masalah-masalah ibadah mahdloh semata, melainkan juga menjadi sumber/instrumen/rujukan dalam menyelesaikan berbagai persoalan sosial yang dihadapi masyarakat, bangsa dan negara.

Beberapa peran yang dapat dilakukan oleh lembaga-lembaga keagamaan ialah sebagai berikut;

1) Membentuk unit khusus yang memiliki konsen terhadap pemberantasan korupsi di setiap lembaga keagamaan yang ada, baik lembaga keagamaan milik pemerintah (seperti lembaga Penyuluh Agama, MUI dan sebagainya), maupun lembaga keagamaan yang memang dibentuk oleh masyarakat (seperti NU, Muhammdiyah, dan sebagainya).

10 A. Rahman Ritonga dan Zainuddin, Fiqh Ibadah, Cet. Ke-2, Jakarta: Gaya Media Pratama, 2002, hlm. 3 . 
2) Menjalin kerja sama dengan berbagai institusi, baik dengan institusi pemerintah maupun swasta untuk secara berkala diberi kesempatan melakukan sosialisasi tentang spirit anti-korupsi kepada seluruh pegawai atau karyawan yang bekerja di dalamnya.

3) Mengingat korupsi juga menjamur tidak hanya di kalangan masyarakat elitis, tetapi juga di kalangan masyarakat menengah ke bawah, maka tokoh agama yang bernaung di berbagai lembaga keagamaan perlu merubah gaya dakwah dari yang hanya sekedar menyampaikan materi berkaitan dengan ibadah mahdlah, menjadi materi-materi yang berisi tentang pentingnya menjaga diri, keluarga dan sanak saudara dari memakan harta haram (seperti korupsi).

4) Melakukan ultimatum berupa dikeluarkannya fatwa yang berisi tentang betapa "najis" dan haramnya harta yang diperoleh dari hasil kejahatan korupsi, dan sekaligus anjuran kepada seluruh tokoh agama dan tokoh masyarakat agar tidak ikut mengkremasi jenazah koruptor, seperti memandikan, mengkafani, menshalati dan menguburkannya. Hal ini pernah dilakukan oleh Rasulullah SAW yang enggan menshalati salah seorang sahabat yang wafat dalam perang khaibar karena telah menggelapkan harta rampasan perang. ${ }^{11}$

5) Melakukan gerakan anti-korupsi secara massif di tengah-tengah masyarakat yang didampingi oleh para tokoh agama agar tidak memberikan kedudukan atau posisi-posisi penting kepada para koruptor di lingkungannya. Hal ini di samping sebagai bentuk dukungan masyarakat kepada pemerintah dalam melakukan langkah-langkah preventif terjadinya kejahatan korupsi, juga sebagai upaya menjerakan pelaku korupsi, bahwa di samping sanksi pengadilan yang telah ia jalani, ia juga layak mendapatkan sanksi sosial dari masyarakat berupa pengucilan.

\section{Upaya Memberantas Perilaku Koruptif Perspektif Pancasila}

11 Majelis Tarjih dan Tajdid PP Muhammadiyah, Tim Kerja Gerakan Nasional Pemberantasan Korupsi PBNU dan Kemitraan Bagi Pembaruan Tata Pemerintahan, Telaah Fiqih Korupsi dalam Muhammadiyah dan Nahdlatul Ulama (NU), Koruptor Itu Kafir, Cet. Ke-1, Jakarta: PT. Mizan Publika, 2010, hlm. 138 
a. Pancasila; Budaya Nusantara Yang Religius-Humanis

Keinginan untuk merubah Pancasila sebagai satu-satunya ideologi bangsa Indonesia oleh oknum-oknum tertentu dari dahulu hingga sekarang tidak pernah mampu diwujudkan, karena memang di samping tidak ada ideologi lain yang mampu menandingi Pancasila, ia juga lahir dari rahim masyarakat nusantara. Artinya, tindak-tanduk masyarakat nusantara telah tercermin dalam nilai-nilai yang terkandung dalam Pancasila sejak zaman dahulu. ${ }^{12}$ Nilai-nilai tersebut meliputi nilai religiusitas, nilai kemanusiaan, nilai persatuan, nilai permusyawaratan (demokratis) dan nilai keadilan.

Secara historis, nilai-nilai Pancasila di atas terpotret secara jelas dalam kebiasaan masyarakat nusantara terdahulu, seperti kebiasaan Raja Mulawarman yang mengadakan kenduri dan memberi sedekah kepada para Brahmana, dan sebagai tanda terima kasihnya, para Brahmana membangunkan yupa untuk Raja Mulawarman. Perilaku keduanya diyakini sebagai perilaku mulia, saling mengasihi dan saling memberi. Nilai Ketuhanan tampak dari kebiasaan raja yang mengadakan kenduri, sementara nilai sosial tercermin dalam perilaku raja dan Brahmana tersebut. ${ }^{13}$

Pun demikian, nilai-nilai yang berorientasi pada kesejahteraan masyarakat nampak dari upaya penguasa kerajaan Sriwijaya yang mengintegrasikan seluruh olahan produksi masyarakat ke dalam satu pintu semacam koperasi di era modern, sehingga sangat membantu masyarakat dalam hal memasarkan barang produksinya. Bahkan pada masa ini telah berdiri sebuah universitas agama Budha yang sangat maju, karena banyak pengembara dari negara lain yang belajar agama di tempat ini. Hal ini semakin menguatkan sisi religiusitas masyarakat nusantara. ${ }^{14}$

Kehidupan beragama masyarakat nusantara terlihat tumbuh dengan semangat kehidupan yang bertoleransi tatkala dua agama besar yakni agama Hindu dan agama Budha hidup dengan humanis dan damai secara berdampingan pada masa kerajaan Majapahit. ${ }^{15}$ Pun demikian, semangat dan nilai persatuan yang melekat dalam setiap sanubari rakyat indonesia terbukti dengan perlawanan

12 Effendy Suryana dan Kaswan, Pancasila dan Ketahanan jati Diri Bangsa; Panduan Kuliah di Perguruan Tinggi, Cet. Ke-1, Bandung: PT. Refika Aditama, 2015, hlm. 23.

13 Ibid., hlm. 24-25.

14 Ibid., hlm. 25-26.

15 Ibid., hlm. 28. 
mereka terhadap para penjajah. Berbagai bentuk perlawanan terhadap penjajah diberbagai daerah yang dilancarkan masyarakat pribumi awalnya tidak membuahkan hasil karena perlawanan tersebut sifatnya sporadis, sehingga kemudian muncul gerakan-gerakan pemuda seperti Boedi Oetomo, Sarekat Dagang Islam, Partai Nasional Indonesia (PNI), dan sebagainya yang gerakannya menitikberatkan pada kesatuan bangsa, alhasil mampu menumbuhkan semangat bangsa indonesia untuk merdeka dan berhasil merebut tanah air bangsa dari tangan penjajah dengan semangat persatuan. ${ }^{16}$

Hingga saat ini, nilai religius, nilai budaya, dan nilai adat-istiadat di atas masih dipegang teguh oleh bangsa Indonesia. Hal ini mengindikasikan bahwa Pancasila di samping sebagai ideologi bangsa indonesia, juga menjadi pedoman hidup (way of life) bangsa. Dengan kata lain, Pancasila merupakan budaya nusantara yang penuh dengan semangat dan nilai-nilai religius dan nilai-nilai yang humanis.

\section{b. Korupsi Bertentangan Dengan Nilai-Nilai Pancasila}

Kebiasaan masyarakat nusantara berupa "saling memberi" satu sama lain masih terasa sangat kental sampai kini, masyarakat jawa menyebutnya dengan istilah "ewuh perkewuh". ${ }^{17}$ Sikap demikian di satu sisi memiliki nilai yang positif, tetapi di sisi lain dapat menjadi bumerang bagi masa depan bangsa. Secara dogmatis, pemberian seseorang atas orang lain tidak memiliki sisi negatif, karena Tuhan memang memerintahkan hamba-Nya untuk senang bersedekah, berinfaq, dan sebagainya, bahkan Tuhan sendiri memiliki sifat sebagai Dzat Yang Maha Pemberi. Tetapi jika pemberian itu dimaksudkan untuk melanggar hak orang lain atau membuat orang lain tidak mendapatkan haknya, maka pemberian semacam itu bernilai buruk. Misalnya; di ranah birokratis, kebiasaan saling memberi (ewuh perkewuh) antar masyarakat dengan pejabat ternyata memberi andil besar terjadinya kejahatan korupsi, seperti penyuapan, gratifikasi dan sebagainya. Dengan kata lain, secara kultural korupsi merupakan masalah sosial.

16 Ibid., hlm. 30-33.

17 Widi Nugrahaningsih dan Indah Wahyu Utami, Pancasila Sebagai Sumber Hukum Bagi Anti Korupsi dan Menjunjung Hak Asasi Manusia, dipublikasikan pada Jurnal "Serambi Hukum", Vol. 08 No. 02, Agustus 2014-Januari 2015, hlm. 191. 
Lebih dari itu, korupsi dalam berbagai bentuknya, di samping tidak hanya sekedar menjadi virus berbahaya bagi kehidupan bangsa Indonesia, tetapi juga sangat bertentangan dengan nilai-nilai yang terkandung dalam Pancasila sebagai ideologi bangsa Indonesia. Pertentangan tersebut dapat dibuktikan dalam uraian berikut:

1) Pertentangan korupsi dengan nilai Ketuhanan; ajaran langit menegaskan bahwa seseorang tidak diperkenankan mengganggu hak orang lain, baik harta, nyawa, kasab (pekerjaannya), dan sebagaianya demi mencapai hasratnya untuk memiliki materi berlimpah. Korupsi tidak hanya merusak tatanan kehidupan orang lain secara individual, tetapi dapat merusak seluruh tatanan kehidupan berbangsa dan bernegara.

2) Pertentangan korupsi dengan nilai Kemanusiaan; manusia dalam perspektif Pancasila tidak dipandang sebagai makhluk individu sebagaimana paham yang dianut ideologi liberalism, tidak juga ditafsirkan sebagai makhluk sosial sebagaimana pandangan kelompok penganut paham komunisme. Tetapi dalam kacamata Pancasila, manusia dipandang sebagai makhluk yang seutuhnya, yakni sebagai makhluk individu sekaligus makhluk sosial. ${ }^{18}$ Artinya, manusia (rakyat Indonesia) memiliki hak kebebasan untuk berekspresi, berpendapat, bekerja dan sebagainya, tetapi kebebasan tersebut dibatasi selama tidak melanggar hak orang lain. Oleh karena itu, pengamalan makna "kebebasan" yang dilakukan oleh para koruptor tidak sesuai dengan makna sila kedua dalam Pancasila. Terlebih di dalam sila kedua terdapat frase "adil" dan "beradab". Adil yang dipahami sebagai sikap mau memberikan kepada orang lain apa yang menjadi haknya, ${ }^{19}$ merupakan sikap yang tidak dimiliki oleh koruptor. Sementara beradab yang berakar kata dari "adab" memiliki pengertian sebagai sikap mau mengakui bahwa hak dan kedudukan yang melekat pada seseorang telah sesuai dengan harkat dan martabat yang telah ditentukan Tuhan. Sikap inipun luput dari dalam diri seorang koruptor, karena ia cenderung selalu iri akan harta dan/atau jabatan yang dimiliki orang lain.

18 A. Gunawan Setiardja, Filsafat Pancasila Bagian I, Cet. Ke- XII, Semarang: Universitas Diponegoro, 2002, hlm. 26.

19 Ibid., hlm. 27. 
3) Pertentangan korupsi dengan nilai Persatuan; korupsi tidak hanya dapat merugikan keuangan negara, tetapi juga dapat memecah belah persatuan dan kesatuan bangsa. Dana kesehatan, dana pendidikan, termasuk dana perbaikan infrastruktur yang dikorup oleh oknum tertentu dapat mengakibatkan terjadinya kecemburuan sosial, pada akhirnya juga berdampak pada ketimpangan dalam rangka pemenuhan hak-hak dasar warga negara, baik antar masyarakat kota dengan masyarakat desa, maupun antar masyarakat di pulau Jawa dengan masyarakat-masyarakat lain di luar pulau Jawa.

4) Pertentangan korupsi dengan nilai Demokratis; sikap demokratis hakikatnya merupakan sikap yang sangat menjunjung tinggi kebebasan yang bertanggungjawab. ${ }^{20}$ Seseorang dapat secara bebas mengeskpresikan kehendaknya, seperti berpendapat, berserikat dan berkumpul, tetapi tetap harus dijalankan dengan penuh tanggungjawab. Kendaraan politik semisal parpol yang digunakan sebagai sarana mengeskpresikan diri dalam menyatakan pendapat dan berserikat tidak diperkenankan digunakan sebagai sarana untuk mendapatkan kekuasaan semata dan menyalahgunakan kekuasaan tersebut dengan salah satunya mengabaikan kesejahteraan konstituen (pemilihnya), karena parpol hakikatnya tempat menampung aspirasi masyarakat dan kekuasaan yang diperoleh merupakan amanah rakyat yang harus digunakan untuk mensejahterakan rakyat. Oleh karena itu, seseorang dapat dikatakan sebagai demokrat sejati manakala ia memiliki sikap rendah hati, mempunyai kemampuan untuk menempatkan diri pada tempatnya dan mampu menyadari bahwa dirinya dapat keliru dan orang lain dapat benar.

5) Pertentangan korupsi dengan nilai Keadilan; keadilan dapat dikatakan menjadi syarat mutlak dalam kehidupan berbangsa dan bernegara, karena keadilan dapat mencegah keresahan dan kekacauan yang terjadi di tengahtengah masyarakat, dan dapat mengusahakan serta menjaga keseimbangan antara hak dan kewajiban. Dapat dibayangkan bagaimana akibat yang akan timbul dikemudian hari jika prinsip keadilan ini dilanggar oleh oknum 
pejabat tertentu, misalnya hakim tidak memberikan putusan yang adil karena menerima suap dari salah satu pihak yang berperkara, maka tidak hanya kekacauan yang terjadi, tetapi kepercayaan masyarakat terhadap penegakah hukum yang adil akan sirna.

c. Langkah atau Strategi Memberantas Korupsi Perspektif Pancasila

Sudah waktunya merevitalisasi spirit Pancasila dalam diri setiap warga negara demi memerangi kejahatan korupsi di tubuh bangsa ini, sehingga Pancasila tidak hanya sekedar melekat dalam ingatan kita tanpa memiliki pengaruh apa-apa, tetapi harus selalu menghiasi tindak-tanduk perilaku kita sebagai warga negara. Lebih jauh, Pancasila dilahirkan melalui pertarungan pemikiran dan kepentingan dari berbagai kelompok saat itu, namun ia kemudian lahir dengan semangat persatuan dalam perbedaan demi terwujudnya kehidupan bangsa yang baldatun thayyibun wa rabbun ghafur.

Untuk menjadi bangsa sebagaimana disebutkan di atas, berbagai hambatan dan permasalahan dari yang kecil hingga yang sangat pelik seperti korupsi pasti menghadang dan harus diselesaikan. Pancasila yang memang lahir untuk dijadikan sebagai landasan pembangunan kehidupan bangsa tentu dapat dijadikan sebagai alat untuk memberantas kejahatan korupsi di negeri ini.

Beberapa strategi yang dapat dilakukan dalam upaya pemberantasan kejahatan korupsi berdasarkan nilai-nilai Pancasila ialah sebagai berikut:

1) Menyelesaikan masalah korupsi tidak bisa diberikan kepada lembaga yang dikenal oleh masyarakat sebagai institusi dan penegak hukum di dalamnya korup. Oleh karena itu, negeri ini membutuhkan institusi dan penegak hukum yang khusus menangani persoalan korupsi, seperti KPK dan Pengadilan Tipikor. Aparat penegak hukum didua instansi tersebut, utamanya para hakim harus diseleksi secara ketat tentang kapabilitas, integritas, dan komitmennya terhadap pemberantasan korupsi, bahkan untuk dapat menduduki posisi sebagai penegak hukum kejahatan korupsi mulai dari penyidik hingga hakim haruslah aparat penegak hukum terbaik di negeri ini yang terkenal dalam menjalankan proses peradilan hanya berdasarkan kepada Ketuhanan Yang Maha Esa. 
2) Untuk memberantas korupsi, bangsa ini membutuhkan aparat penegak hukum yang memegang teguh prinsip keadilan dan keadaban. Artinya, aparat penegak hukum yang independen dan berani menolak berbagai upaya intervensi dari pihak manapun, termasuk penguasa. Karena sebagaimana telah disampaikan dalam uraian sebelumnya bahwa ketika aparat penegak hukum adil dan beradab, maka ia tidak akan mudah tergiur godaan materi sebagai salah satu upaya mengintervensi keputusannya, sehingga akan menghukum bersalah orang yang memang bersalah.

3) Bangsa Indonesia harus bersinergi dalam kesatuan demi terbebasnya negeri ini dari penyakit korupsi. Prinsip kesadaran bersama dalam memberantas korupsi menjadi tolak ukur bahwa seluruh elemen bangsa menolak keberadaan korupsi di negeri ini. Dengan kata lain, untuk memerangi korupsi tidak cukup hanya dengan berpangku tangan kepada aparat penegak hukum, tetapi rakyat dan seluruh elemen sosial lainnya di samping memiliki kesadaran akan bahaya korupsi, juga harus aktif melakukan kontrol dan/atau pengawasan terhadap jalannya pemerintahan, mulai dari perencanaan anggaran, hingga tercapai dan tidaknya target yang dituju pemerintah. Yang juga tidak kalah pentingnya adalah bagaimana membentuk psikologi masyarakat, khususnya anak-anak generasi bangsa untuk sangat membenci perilaku korup dalam berbagai bentuknya, misalnya dengan membuat aplikasi game yang isinya adalah menyiksa pelaku korupsi.

4) Demokrasi yang dijalankan bangsa Indonesia merupakan demokrasi yang sangat menjunjung tinggi kedaulatan rakyat yang dijiwai oleh volgeist-nya sendiri, yakni nilai-nilai Pancasila. Dalam demokrasi yang berdasarkan nilai-nilai Pancasila terkandung jaminan keselarasan antara kepentingan individu dan kepentingan publik, sehingga dapat mencegah terjadinya tindakan-tindakan diskriminatif oleh yang kuat terhadap yang lemah, baik melalui saluran ekonomi maupun politik. Lebih jauh, demokrasi Pancasila juga mengandung sikap dasar bahwa kepentingan dan keselamatan bersama harus didudukkan di atas kepentingan individu maupun kelompok. ${ }^{21}$ Artinya, tidak mungkin terjadi korupsi jika demokrasi ini diamalkan dengan 
baik dalam berbagai segi kehidupan bangsa. Oleh karena itu, penting diadakannya sosialisasi Pancasila dalam setiap wadah aspirasi masyarakat, baik yang berbentuk partai politik, lembaga swadaya masyarakat, lembagalembaga birokrasi pemerintah, dan sebagainya, dengan tujuan untuk menanamkan spirit kesabaran untuk tunduk pada kepentingan bersama demi mewujudkan demokrasi Pancasila di negeri ini.

5) Demi mewujudkan keadilan sosial bagi seluruh rakyat indonesia, maka penegakan hukum yang berat terhadap pelaku kejahatan korupsi harus dilakukan demi menjerakan pelaku. Di samping itu, pengawasan terhadap jalannya masa pemidanaan pelaku koruptor di rumah tahanan penting dilakukan secara berkala dan berkelanjutan. Artinya antara vonis berat dan pengawasan terhadap koruptor harus seimbang, sehingga tidak terjadi lagi peristiwa seperti rumah tahanan yang memiliki fasilitas mewah, koruptor memiliki rumah mewah di sekitar lapas, dan sebagainya.

\section{SIMPULAN}

Berdasarkan pembahasan penelitian yang diuraikan di atas, dapat diambil suatu kesimpulan bahwa:

1. Lembaga keagamaan memiliki peran/andil yang cukup besar dalam memberantas korupsi. Peran tersebut dapat diwujudkan antara lain melalui; pembentukan unit khusus yang konsen terhadap pemberantasan korupsi di setiap lembaga keagamaan, menjalin kerja sama dengan instansi lain untuk melakukan sosialisasi bahaya korupsi, merubah gaya dakwah yang tidak sekedar menyampaikan hal-hal seputar ibadah mahdlah tetapi lebih kepada penyampaian materi akan pentingnya menjaga diri, keluarga dan sanak saudara dari memakan harta haram, mengeluarkan fatwa tentang najis dan haramnya harta yang diperoleh dari hasil korupsi sekaligus anjuran kepada tokoh agama dan tokoh masyarakat untuk tidak mengkremasi jenazah koruptor dan mengucilkan para koruptor di tengah-tengah masyarakat.

2. Adapun strategi memberantas korupsi dalam perspektif Pancasila dapat dilakukan antara lain melalui; menempatkan aparat penegak hukum terbaik di kursi-kursi penting dalam lembaga-lembaga anti korupsi, menumbuhkan kesadaran akan 
bahaya korupsi di seluruh elemen masyarakat misalnya melalui pembuatan game yang isinya menyiksa pelaku korupsi serta pelibatan masyarakat dalam melakukan pengawasan terhadap jalannya pemerintahan, melakukan sosialiasi tentang pengamalan nilai-nilai Pancasila di setiap wadah aspirasi masyarakat dan memberikan vonis hukuman berat terhadap pelaku korupsi yang disertai pengawasan terhadap jalannya masa pemidanaan para koruptor secara berkala dan berkelanjutan.

\section{DAFTAR PUSTAKA}

\section{Buku:}

Kitab Suci Al-Qur'an.

al-Turmuzi, Abu 'Isa Muhammad ibn 'Isa ibn Tsaurat. t.th. Sunan al- Turmuzi (Jami' al-Shahih), Indonesia: Dahlan, kitab ahkam, no. 1257, juz 2, hal. 397. Abu Hasan mengatakan bahwa hadits ini shohih hasan

an-Nawawi, Imam Yahya bin Syarf ad-Din. t.tt. Matan Al-Arba'in An-Nawawiyah, Maktabah: Syaikh Salim ibn Sa'ad Nabhani

Danil, Elwi. 2012. Korupsi: Konsep, Tindak Pidana, dan Pemberantasannya, Jakarta: PT. RajaGrafindo Persada

HR. Ahmad, hadits ini dijadikan sebagai salah satu rujukan dalam Musyawarah Nasional VI Majelis Ulama Indonesia yang berlangsung pada tanggal 23-27 Rabi'ul Akhir/ 25-29 Juli 2000 M, yang membahas tentang Suap (Risywah), Korupsi (Ghulul) dan Hadiah kepada Pejabat, hadist ini kemudian terhimpun dalam Himpunan Fatwa Majelis Ulama Indonesia

Khallaf, Abd Wahab. 1990. Ilm Ushul al-Fiqh, Kairo: Dar al-Qalam

Majelis Tarjih dan Tajdid PP Muhammadiyah, Tim Kerja Gerakan Nasional Pemberantasan Korupsi PBNU dan Kemitraan Bagi Pembaruan Tata Pemerintahan. 2010. Telaah Fiqih Korupsi dalam Muhammadiyah dan Nahdlatul Ulama (NU), Koruptor Itu Kafir, Cet. Ke-1, Jakarta: PT. Mizan Publika 
Ritonga, A. Rahman dan Zainuddin. 2002. Fiqh Ibadah, Cet. Ke-2, Jakarta: Gaya Media Pratama.

Ruslan, Idrus, "Reorientasi Fungsi Lembaga-Lembaga Keagamaan Dalam Meningkatkan Perilaku Umat Beragama Yang Inklusif (Studi Terhadap MUI, PGI, PHDI, dan Walubi Provinsi Lampung)", Pusat Penelitian dan Penerbitan Lembaga Penelitian dan Pengabdian Kepada Masyarakat (LP2M) IAIN Raden Intan Lampung, 2014.

Setiardja, A. Gunawan. 2002. Filsafat Pancasila Bagian I, Cet. Ke- XII, Semarang: Universitas Diponegoro.

Suryana, Effendy dan Kaswan. 2015. Pancasila dan Ketahanan jati Diri Bangsa; Panduan Kuliah di Perguruan Tinggi, Cet. Ke-1, Bandung: PT. Refika Aditama.

\section{Jurnal:}

Fawaid, Muhammad Wildan, "Pengaruh Harta Halal dan Haram Pada Umat", Jurnal Masharif al-Syari'ah, Vol. 1 No. 2 November 2016

Marzuki, Ismail, "Melumpuhkan Tindak Pidana Pencucian Uang Dengan Hukum Pidana Islam”, Jurnal Wajah Hukum, Vol. 1 No. 1 Oktober 2017

Nugrahaningsih, Widi dan Indah Wahyu Utami, "Pancasila Sebagai Sumber Hukum Bagi Anti Korupsi dan Menjunjung Hak Asasi Manusia”, Jurnal Serambi Hukum, Vol. 08 No. 02 Agustus 2014-Januari 2015

\section{Peraturan Perundang-undangan:}

Republik Indonesia, Penjelasan atas Undang-Undang Republik Indonesia Nomor 30 Tahun 2002 tentang Komisi Pemberantasan Tindak Pidana Korupsi. 